\title{
Caylobolide B, a Macrolactone from Symplostatin 1-Producing Marine Cyanobacteria Phormidium spp. from Florida
}

\author{
Lilibeth A. Salvador ${ }^{\dagger}$, Valerie J. Paul ${ }^{\ddagger}$, and Hendrik Luesch ${ }^{\dagger,}$ \\ Department of Medicinal Chemistry, University of Florida, 1600 SW Archer Road, Gainesville, \\ Florida 32610, and Smithsonian Marine Station, 701 Seaway Drive, Fort Pierce, Florida 34949
}

\begin{abstract}
A Phormidium spp. collection from Key West, Florida afforded caylobolide B (1), an analogue of the known macrolactone caylobolide A, previously isolated from a Lyngbya majuscula collection from the Bahamas. The planar structure of $\mathbf{1}$ was determined using NMR and MS experiments. The relative configuration for subunits C7-C9 and C25-C29 was assigned using Kishi's Universal NMR database. Caylobolide B (1) displayed cytotoxic activity against HT29 colorectal adenocarcinoma and HeLa cervical carcinoma cells with $\mathrm{IC}_{50}$ values of $4.5 \mu \mathrm{M}$ and $12.2 \mu \mathrm{M}$, respectively.
\end{abstract}

Marine cyanobacteria have been prolific sources of bioactive and structurally intriguing natural products. Secondary metabolites from these organisms mainly consist of nonribosomally derived peptides and peptide-polyketide hybrids. ${ }^{1,2}$ Pure polyketides, assembled only by polyketide synthases, represent a minor fraction of isolated compounds from the phylum Cyanobacteria. These usually polyhydroxylated compounds are reminiscent of secondary metabolites from dinoflagellates ${ }^{3}$ such as the cytotoxic amphidinolides, amphidinols and luteophanols as well as bacteria-derived antibiotics, desertomycins ${ }^{4}$ and oasomycins. ${ }^{5}$

Polyketides from marine and terrestrial cyanobacteria also possess interesting biological activities and may be decorated with unusual moieties. Tolytoxin and the related scytophycins, produced by terrestrial cyanobacteria, are potent cytotoxins. ${ }^{6}$ Tolytoxins are distinguished by an epoxide substituent in their backbone structure. Oscillariolide, ${ }^{7}$ a polyketide isolated from the genus Oscillatoria, inhibited the development of fertilized echinoderm eggs, suggestive of its effects on cell division. Phormidolide, ${ }^{8}$ a compound related to oscillariolide, was isolated from the genus Phormidium and is also a potent cytotoxin. Both oscillariolide and phormidolide macrocycles contain a tetrahydrofuran ring and a terminal vinyl bromide appended to their ring structure. In addition, one hydroxy group in phormidolide is esterified with a C-16 carboxylic acid. The well-studied marine cyanobacterium Lyngbya majuscula afforded the polyketide caylobolide A that is characterized by its contiguous pentad of 1,5 diols. ${ }^{9}$

The structure elucidation of polyketides is particularly challenging due to difficulty in establishing the relative and absolute configuration of the multiple stereocenters and substantial overlap in the methylene region. Their configurational assignment has greatly

\footnotetext{
* To whom correspondence should be addressed. Tel.: (352) 273-7738. Fax: (352) 273-7741. luesch@ cop.ufl.edu..

University of Florida.

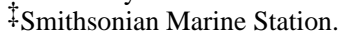

Supporting Information Available: ${ }^{1} \mathrm{H},{ }^{13} \mathrm{C}$, and 2D NMR spectra for compound $1 .{ }^{1} \mathrm{H}$ NMR spectrum for symplostatin 1 . This material is available free of charge via the Internet at http://pubs.acs.org.
} 
benefited from the development of Kishi's Universal NMR database ${ }^{10-12}$ as well as derivatization techniques, particularly Mosher's analysis ${ }^{13}$ and extensions of this method, ${ }^{14}$ although applications still have certain limitations, particularly for those bearing $1, n$ diol ( $n$ $>5$ ) moieties. Assignment of the configuration of $1, n$ diols has so far been demonstrated on model systems using exciton coupling CD after derivatization with arylcarboxylate chromophores within liposomes. ${ }^{15}$

In this paper, we report the isolation, structure elucidation, and cytotoxic activity of a new macrolactone analogue of caylobolide $\mathrm{A}^{9}$ from a collection of Phormidium spp., termed caylobolide B (1). Compound 1 showed micromolar cytotoxic activity against several cancer cell lines.

A freeze-dried sample of an assemblage of $P$. cf. dimorphum and $P$. inundatum from Key West, Florida was extracted with EtOAc-MeOH (1:1). The resulting nonpolar extract was solvent partitioned to yield the hexanes-, $n$ - $\mathrm{BuOH}-$ and $\mathrm{H}_{2} \mathrm{O}-$ soluble fractions. The $n-\mathrm{BuOH}$ fraction was cytotoxic to HT29 colorectal adenocarcinoma cells and subjected to bioactivityguided isolation using silica gel chromatography and reversed-phase HPLC to yield caylobolide B (1) (Figure 1). The major cytotoxic activity was attributed to the known compound symplostatin 1, a microtubule depolymerizing agent, as evidenced from comparison of ${ }^{1} \mathrm{H}$ NMR and LRESIMS data with reported values. ${ }^{16-18}$

Caylobolide B (1) was isolated as a colorless, amorphous solid with molecular formula of $\mathrm{C}_{42} \mathrm{H}_{80} \mathrm{O}_{11}$ based on pseudomolecular ion peaks observed by HRESI/APCIMS at $\mathrm{m} / \mathrm{z}$ $761.5767[\mathrm{M}+\mathrm{H}]^{+}$and $m / z 783.5594[\mathrm{M}+\mathrm{Na}]^{+}$. Fragmentation of the $[\mathrm{M}+\mathrm{H}]^{+}$peak using positive ionization showed repetitive loss of $18 \mathrm{amu}$, corresponding to elimination of $\mathrm{H}_{2} \mathrm{O}$ typical for alcohols. The structure of 1 was determined by NMR analysis in DMSO- $d_{6}$. The presence of exchangeable hydroxy protons was evident from the lack of HSQC correlations for nine protons which resonate at $\delta_{\mathrm{H}} 4.2-4.6 \mathrm{ppm}$. Detailed interpretation of HSQC, TOCSY, HSQC-TOCSY and HMBC experiments with 1 (Table 1, Figure 2) established that the hydroxy groups are part of methine carbinols that form a highly oxygenated backbone structure consisting of a 1,3-diol system (C-7, C-9), a 1,3,5-triol system (C-25, C-27, C-29) and repeating 1,5-diol moieties. Degenerate ${ }^{1} \mathrm{H}$ and ${ }^{13} \mathrm{C}$ NMR chemical shifts were observed for three oxygenated methines at $\delta_{\mathrm{C}} 69.6$ (C-13, C-17, C-21), seven methylenes at $\delta_{\mathrm{C}} 37.3$ (C-12, C-14, C-16, C-18, C-20, C-22, C-24), and two methylenes at $\delta_{\mathrm{C}} 21.6$ (C-15, C-19) that make up the contiguous chain of 1,5 -diol. The ${ }^{13} \mathrm{C}$ NMR chemical shifts are in good agreement with reported values for the 1,5-diol units of luteophanol. ${ }^{19}$ These degenerate signals together with HSQC-TOCSY correlations (Figure 2) between $\delta_{\mathrm{C}} 37.3 / \delta_{\mathrm{H}} 4.20$ and $\delta_{\mathrm{C}} 21.6 / \delta_{\mathrm{H}} 4.20$ supported the 1,5-diol substitution pattern. HSQC-TOCSY correlations (Figure 2) between C-15/9-OH, C-23/25-OH suggested that the contiguous chain of 1,5-diol is flanked by the 1,3-diol and 1,3,5-triol units. HSQC-TOCSY correlations between C-31/29-OH, C-32/29-OH, C-32/33-OH, C-33/H-35 enabled the extension of the polyhydroxylated chain which terminates to form an ester linkage with a carbonyl group at $\delta_{\mathrm{C}} 165.4(\mathrm{C}-1)$. The low-field chemical shift of H-35 $\left(\delta_{\mathrm{H}} 5.00\right)$ - due to anisotropy from an unsaturated system - and a HMBC correlation between $\mathrm{C}-1 / \mathrm{H}-35$ confirmed the presence of the ester linkage. From HMBC and TOCSY correlations of C-35/H35 (Table 1), it was evident that C-35 was modified by an isohexyl side chain substitution. An additional unsaturation is present in $\mathbf{1}$ due to a carbon-carbon double bond between $\mathrm{C}-2$ and $\mathrm{C}-3$. HMBC correlations $(\mathrm{C}-1 / \mathrm{H}-2, \mathrm{C}-3 / \mathrm{H}-2)$ and the characteristic chemical shifts for $\mathrm{C}-2\left(\delta_{\mathrm{C}}\right.$ $116.5)$ and $\mathrm{C}-3\left(\delta_{\mathrm{C}} 159.4\right)$ were suggestive of a polarized carbon-carbon double bond, consistent with an $\alpha, \beta$-unsaturated ester functionality. HMBC correlations between $\mathrm{C}$-2/ $\mathrm{H}_{3}-42$ and $\mathrm{C}-3 / \mathrm{H}_{3}-42$ indicated a methyl substitution at the $\beta$ position. 
The structure of $\mathbf{1}$ bears a close resemblance to the 36-membered macrolactone ring present in the known compound caylobolide A (Figure 1) and was therefore termed caylobolide B. The C-1 to C-9 portion of these compounds presents a major difference, where an additional carbon-carbon double bond and a different hydroxylation pattern are present in $\mathbf{1}$. The isolated 1,3-diol system (C-7 to C-9) is a distinctive feature of $\mathbf{1}$, instead of a 1,5-diol unit from C-5 to C-9 in caylobolide A. The structure of caylobolide B (1) was confirmed using ESIMS fragmentation in the negative ionization mode (Figure 3). It was evident that fragmentation occurred mainly at positions $\alpha$ - and $\beta$ - to the hydroxy groups, similar to fragmentation patterns observed for amphidinols. ${ }^{20}$

The relative configuration of selected stereogenic centers of $\mathbf{1}$ was assigned by independently considering the 1,3-diol and 1,3,5-triol moieties using Kishi's Universal NMR Database (Database 2). ${ }^{10-12}$ The ${ }^{13} \mathrm{C}$ NMR chemical shifts of C-7/C-9 were in good agreement with syn arrangement of 1,3-diol model system (Figure 4). The 1,3,5- triol system was assigned as either syn/anti or anti/syn between C-25/C-27, C-27/C-29 based on comparison of $\delta_{\mathrm{C}}$ at C-27 with the characteristic $\delta_{\mathrm{C}}$ of the central carbon of the 1,3,5-triol model system (Figure 4). This method cannot differentiate between syn/anti or anti/syn orientation. Unfortunately, Mosher's analysis failed to give any conclusive result on the absolute configuration and was limited by the low yield of $\mathbf{1}$. The lack of chemical shift dispersion in the contiguous chain of 1,5 diol in caylobolide B limits the assignment of the absolute configuration in this moiety. The determination of the complete stereostructure may require chemical methods coupled with $\mathrm{CD}$ spectroscopy or new derivatization techniques.

Caylobolide B (1) exhibited cytotoxic activity against HT29 colorectal adenocarcinoma and HeLa cervical carcinoma cells with $\mathrm{IC}_{50}$ of $4.5 \mu \mathrm{M}$ and $12.2 \mu \mathrm{M}$, respectively. The cytotoxic activity of $\mathbf{1}$ is comparable to that of caylobolide A against HCT116 colon carcinoma cells $\left(\mathrm{IC}_{50} 9.9 \mu \mathrm{M}\right){ }^{9}{ }^{9}$ The activity of the nonpolar extract was dominated by symplostatin 1 (HT29 IC $50 \sim 1.5 \mathrm{nM}$ ), however, because our cyanobacterial collection was largely a binary mixture of two different Phormidium species, it is unclear if caylobolide B (1) and the coisolated cytotoxin symplostatin 1 were produced by the same or both species.

\section{Experimental Section}

\section{General Experimental Procedures}

The optical rotation was measured on a Perkin-Elmer 341 polarimeter. The UV spectrum was recorded on SpectraMax M5 Molecular Devices. ${ }^{1} \mathrm{H}$ and 2D NMR spectra were recorded in DMSO- $d_{6}$ on a Bruker Avance II $600 \mathrm{MHz}$ spectrometer equipped with a 5-mm triple resonance high-temperature superconducting (HTS) cryogenic probe using residual solvent signals $\left(\delta_{\mathrm{H}} 2.50 ; \delta_{\mathrm{C}} 39.5\right)$ as internal standards. The ${ }^{13} \mathrm{C}$ NMR spectrum was recorded in DMSO- $d_{6}$ on a Bruker $500 \mathrm{MHz}$ spectrometer, operating at $125 \mathrm{MHz}$. HSQC and HMBC experiments were optimized for ${ }^{1} J_{\mathrm{CH}}=145$ and ${ }^{n} J_{\mathrm{CH}}=7 \mathrm{~Hz}$, respectively. TOCSY and HSQC-TOCSY experiments were done using a mixing time of $100 \mathrm{~ms}$. HRMS data was obtained using an Agilent LC-TOF mass spectrometer equipped with an APCI/ESI multimode ion source detector. ESI-MS/MS data were obtained on a 3200 QTRAP (Applied Biosystems) by direct injection using a syringe driver.

\section{Biological Material}

The cyanobacteria, Phormidium spp., were hand collected on June 24, 2008 at the breakwater at Fort Zachary Taylor State Park (Key West), Florida by snorkeling in shallow waters. The collection was later identified to consist primarily of $P$. cf. dimorphum and $P$. inundatum. Voucher specimens (\#VP_6_24_08_FZT1) are maintained at Smithsonian Marine Station, Fort Pierce, Florida. 


\section{Extraction and Isolation}

The freeze-dried organism (54.16 g) was extracted with EtOAc-MeOH (1:1) to yield $5.7 \mathrm{~g}$ of the nonpolar extract. Subsequent extraction of the freeze-dried material with EtOH- $\mathrm{H}_{2} \mathrm{O}$ (1:1) gave $11.5 \mathrm{~g}$ of the polar extract. The nonpolar extract was further partitioned between hexanes and $20 \%$ aqueous $\mathrm{MeOH}$. The latter was concentrated under reduced pressure and was further partitioned between $n$ - $\mathrm{BuOH}$ and $\mathrm{H}_{2} \mathrm{O}$. The $n-\mathrm{BuOH}(0.56 \mathrm{~g})$ fraction was concentrated and subjected to $\mathrm{Si}$ gel column chromatography eluting first with $\mathrm{CH}_{2} \mathrm{Cl}_{2}$, followed by increasing concentrations of $i$-PrOH. After $100 \% i$-PrOH, increasing gradients of $\mathrm{MeOH}$ were used until $100 \% \mathrm{MeOH}$. The fraction that eluted with $25 \% \mathrm{MeOH}$ was subjected to reversed-phase HPLC (semipreparative, Phenomenex Synergi-Hydro RP, $4 \mu \mathrm{m}$ ) using a linear gradient of $\mathrm{MeOH}-\mathrm{H}_{2} \mathrm{O}(40 \%-100 \% \mathrm{MeOH}$ in 40 min and then $100 \% \mathrm{MeOH}$ for $10 \mathrm{~min})$ to yield caylobolide $\mathrm{B}(\mathbf{1})\left(t_{\mathrm{R}} 31.1 \mathrm{~min}, 2.1 \mathrm{mg}\right)$. Purification of the fraction from $50 \% \mathrm{MeOH}$ using the same condition yielded symplostatin $1\left(t_{\mathrm{R}} 31.4 \mathrm{~min}, 1.5 \mathrm{mg}\right)$.

Caylobolide B (1): colorless, amorphous solid; $[\alpha]^{20}{ }_{\mathrm{D}}-15$ ( $c$ 0.15, MeOH); UV (MeOH); $\lambda_{\max }(\log \varepsilon) 215$ (4.09); ${ }^{1} \mathrm{H}$ NMR, ${ }^{13} \mathrm{C}$ NMR, TOCSY, and HMBC data, see Table 1; HRESI/APCIMS $m / z 761.5767[\mathrm{M}+\mathrm{H}]^{+}\left(\right.$calcd for $\mathrm{C}_{42} \mathrm{H}_{81} \mathrm{O}_{11}, 761.5779$ ); $\mathrm{m} / 2.783 .5594$ $[\mathrm{M}+\mathrm{Na}]^{+}$(calcd for $\left.\mathrm{C}_{42} \mathrm{H}_{80} \mathrm{O}_{11} \mathrm{Na}, 783.5593\right)$.

Symplostatin 1: colorless, amorphous solid; $[\alpha]^{20}{ }_{\mathrm{D}}-98(c 0.03, \mathrm{MeOH})\left\{\right.$ lit. $^{16}[\alpha]_{\mathrm{D}}-45(c$ $1.6, \mathrm{MeOH})\} ; \mathrm{UV}(\mathrm{MeOH}) ; \lambda_{\max }(\log \varepsilon) 204$ (3.52), 240 (2.94); ${ }^{1} \mathrm{H}$ NMR spectrum is identical with that of an authentic sample, ${ }^{16}$ see Supporting Information; LRESIMS $\mathrm{m} / \mathrm{z}$ $799.3[\mathrm{M}+\mathrm{H}]^{+}$.

\section{ESI-MS/MS Fragmentation}

A solution of $\mathbf{1}$ in $\mathrm{MeOH}$ was directly infused into the mass spectrometer using a syringe driver. MS fragmentation was obtained by positive and negative ionization using the Enhanced Product Ion (EPI) and MS2 scan. The $[\mathrm{M}+\mathrm{H}]^{+}\left(\mathrm{m} / \mathrm{z}\right.$ 761.6) and $[\mathrm{M}-\mathrm{H}]^{-}$ions $(\mathrm{m} / \mathrm{z}$ 759.6) were fragmented by ramping the collision energy through the possible allowed range. Compound dependent and source gas parameters used were as follows: DP +/-65.0, EP +/ -10.0, CUR 10.0, CAD High, IS +/-4500, TEM 0, GS1 10, GS2 0.

\section{MTT Cell Viability Assay}

HT29 colorectal adenocarcinoma and HeLa cervical carcinoma cells were cultured in Dulbecco's modified Eagle medium (DMEM, Invitrogen) supplemented with 10\% fetal bovine serum (FBS, Hyclone) under a humidified environment with $5 \% \mathrm{CO}_{2}$ at $37{ }^{\circ} \mathrm{C}$. HeLa $(3,000)$ and HT29 $(12,500)$ cells were seeded in 96-well plates with varying concentrations of 1 added to each well $24 \mathrm{~h}$ later, with treatments done in duplicate. The cells were incubated for an additional $48 \mathrm{~h}$ before the addition of the MTT reagent. Cell viability was measured according to the manufacturer's instructions (Promega).

\section{Supplementary Material}

Refer to Web version on PubMed Central for supplementary material.

\section{Acknowledgments}

This research was supported by the National Institutes of Health, NIGMS grant P41GM086210. We thank Fort Zachary Taylor State Park for granting permission for sample collection. We are grateful to D. Littler for identifying the cyanobacteria, to J. Kwan and R. Ritson-Williams for collecting and extracting the cyanobacteria, and to J. Rocca for assistance in obtaining the NMR spectra. This is contribution \#832 from the Smithsonian Marine Station. 


\section{References and Notes}

1. Tan LT. Phytochemistry. 2007; 68:954-979. [PubMed: 17336349]

2. Liu L, Rein KS. Mar. Drugs. 2010; 8:1817-1837. [PubMed: 20631872]

3. Kobayashi J, Kubota T. J. Nat. Prod. 2007; 70:451-460. [PubMed: 17335244]

4. Zerlin M, Thiericke R. J. Org. Chem. 1994; 59:6986-6993.

5. Kretzschmar G, Krause M, Radics L. Tetrahedron. 1997; 53:971-986.

6. Carmeli S, Moore RE, Patterson GML. J. Nat. Prod. 1990; 53:1533-1542. [PubMed: 2128517]

7. Murakami M, Matsuda H, Makabe K, Yamaguchi K. Tetrahedron Lett. 1991; 32:2391-2394.

8. Williamson RT, Boulanger A, Vulpanovici A, Roberts MA, Gerwick WH. J. Org. Chem. 2002; 67:7927-7936. [PubMed: 12423120]

9. MacMillan JB, Molinski TF. Org. Lett. 2002; 4:1535-1538. [PubMed: 11975622]

10. Kobayashi Y, Tan C-H, Kishi Y. Helv. Chim. Acta. 2000; 83:2562-2571.

11. Kobayashi Y, Tan C-H, Kishi Y. Angew. Chem. Int. Ed. 2000; 39:4279-4281.

12. Kobayashi Y, Tan C-H, Kishi Y. J. Am. Chem. Soc. 2001; 123:2076-2078. [PubMed: 11456839]

13. Sullivan GR, Dale JA, Mosher HS. J. Org. Chem. 1973; 38:2143-2147.

14. Seco JM, Quinoá E, Riguera R. Tetrahedron: Asymmetry. 2001; 12:2915-2925.

15. MacMillan JB, Molinski TF. J. Am. Chem. Soc. 2004; 126:9944-9945. [PubMed: 15303868]

16. Harrigan GG, Luesch H, Yoshida WY, Moore RE, Nagle DG, Paul VJ, Mooberry SL, Corbett TH, Valeriote FA. J. Nat. Prod. 1998; 61:1075-1077. [PubMed: 9748368]

17. Luesch H, Moore RE, Paul VJ, Mooberry SL, Corbett TH. J. Nat. Prod. 2001; 64:907-910. [PubMed: 11473421]

18. Mooberry SL, Leal RM, Tinley TL, Luesch H, Moore RE, Corbett TH. Int. J. Cancer. 2003; 104:512-521. [PubMed: 12584751]

19. Kubota T, Tsuda M, Doi Y, Takahashi A, Nakamichi H, Ishibashi M, Fukushi E, Kawabata J, Kobayashi J. Tetrahedron. 1998; 54:14455-14464.

20. Meng Y, Van Wagoner RM, Misner I, Tomas C, Wright JLC. J. Nat. Prod. 2010; 73:409-415. [PubMed: 20108948] 


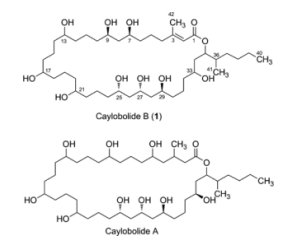

Figure 1.

Caylobolide B (1) and closely related compound caylobolide A. The absolute configuration for $\mathrm{C} 25, \mathrm{C} 27$ and C29 is proposed by analogy to caylobolide A. Only the relative configuration is shown for $\mathrm{C} 7$ and $\mathrm{C} 9$, which could not be related to $\mathrm{C} 25-\mathrm{C} 29$. 


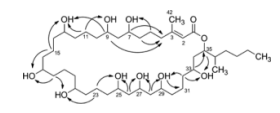

Figure 2.

Key HSQC-TOCSY correlations. 


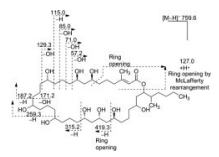

Figure 3.

ESI-MS/MS of caylobolide B (1). 


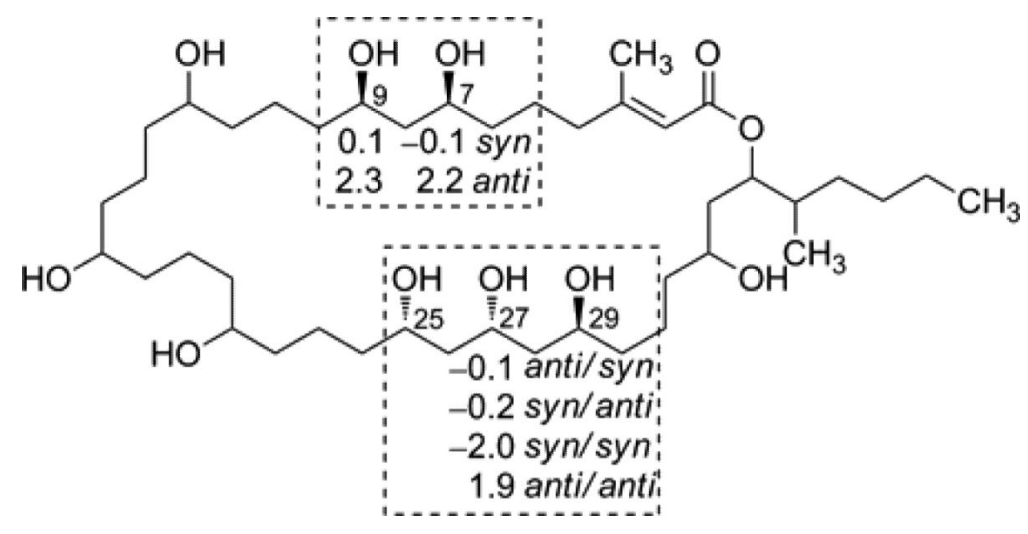

Figure 4.

Assignment of the relative configuration of caylobolide B (1) based on Kishi's Universal NMR Database (Database 2). $\Delta \delta$ values between the model system and $\mathbf{1}$ are shown. The relative configuration shown is based on the best fit with the model system. The 1,3-diol is assigned as syn. The $\Delta \delta$ values for the characteristic central carbon of the 1,3,5-triol system suggest either anti/syn or syn/anti arrangement. 
Table 1

NMR Data for Caylobolide B (1) in DMSO- $d_{6}$

\begin{tabular}{|c|c|c|c|c|}
\hline Position & $\delta_{\mathrm{C}}^{a}$ & $\delta_{\mathbf{H}}(J \text { in } \mathbf{H z})^{b}$ & HМBC $^{b}$ & TOCSY $b$ \\
\hline 1 & $165.4, \mathrm{C}$ & & & \\
\hline 2 & $116.5, \mathrm{CH}$ & $5.63, \mathrm{~s}$ & $1,3,42$ & $\mathrm{H}-4 \mathrm{a}, \mathrm{H}-4 \mathrm{~b}, \mathrm{H}_{3}-42$ \\
\hline 3 & $159.4, \mathrm{C}$ & & & \\
\hline $4 \mathrm{a}$ & $32.8, \mathrm{CH}_{2}$ & $2.64, \mathrm{~m}$ & $2,3,5,42$ & $\mathrm{H}-2, \mathrm{H}-4 \mathrm{~b}, \mathrm{H}-5 \mathrm{a}, \mathrm{H}-7,7-\mathrm{OH}$ \\
\hline $4 \mathrm{~b}$ & & $2.42, \mathrm{~m}$ & $2,3,5,42$ & H-2, H-4a, H-5a, H-7, 7-OH \\
\hline $5 \mathrm{a}$ & 23.6, $\mathrm{CH}_{2}$ & $1.52, \mathrm{~m}$ & & $\mathrm{H}-4 \mathrm{a}, \mathrm{H}-4 \mathrm{~b}$ \\
\hline $5 b$ & & $1.40, \mathrm{~m}$ & 7 & $\mathrm{H}-4 \mathrm{a}, \mathrm{H}-4 \mathrm{~b}$ \\
\hline 6 & $37.1, \mathrm{CH}_{2}$ & $1.37, \mathrm{~m}$ & & \\
\hline 7 & $68.8, \mathrm{CH}$ & $3.58, \mathrm{~m}$ & 9 & $\mathrm{H}-4 \mathrm{a}, \mathrm{H}-4 \mathrm{~b}, \mathrm{H}-5 \mathrm{a}, 7-\mathrm{OH}$ \\
\hline $7-\mathrm{OH}$ & & $4.52, \mathrm{~d}(4.4)$ & $6,7,8$ & H-4a, H-4b, H-5a, H-6, H-7 \\
\hline 8 & $44.15, \mathrm{CH}_{2}$ & $1.39, \mathrm{~m}$ & & \\
\hline 9 & $69.0, \mathrm{CH}$ & $3.54, \mathrm{~m}$ & 10 & 13-OH, 9-OH \\
\hline 9-OH & & $4.47, \mathrm{~d}(4.8)$ & $8,9,10$ & H-9, H-13 \\
\hline 10 & 37.6, $\mathrm{CH}_{2}$ & $1.28, \mathrm{~m}$ & & \\
\hline 11 & $21.3, \mathrm{CH}_{2}$ & $1.21, \mathrm{~m}$ & & \\
\hline 12 & $37.3, \mathrm{CH}_{2}$ & $1.28, \mathrm{~m}$ & & \\
\hline 13 & $69.6, \mathrm{CH}$ & $3.35, \mathrm{~m}$ & & 9-OH, 13-OH \\
\hline $13-\mathrm{OH}$ & & $4.20, \mathrm{~m}$ & $12,13,14$ & $\mathrm{H}-9, \mathrm{H}-13$ \\
\hline 14 & $37.3, \mathrm{CH}_{2}$ & $1.28, \mathrm{~m}$ & & \\
\hline 15 & 21.6, $\mathrm{CH}_{2}$ & $1.21, \mathrm{~m}$ & & \\
\hline 16 & $37.3, \mathrm{CH}_{2}$ & $1.28, \mathrm{~m}$ & & \\
\hline 17 & $69.6, \mathrm{CH}$ & $3.37, \mathrm{~m}$ & & $17-\mathrm{OH}$ \\
\hline $17-\mathrm{OH}$ & & $4.20, \mathrm{~m}$ & $16,17,18$ & $\mathrm{H}-17$ \\
\hline 18 & $37.3, \mathrm{CH}_{2}$ & $1.28, \mathrm{~m}$ & & \\
\hline 19 & 21.6, $\mathrm{CH}_{2}$ & $1.21, \mathrm{~m}$ & & \\
\hline 20 & $37.3, \mathrm{CH}_{2}$ & $1.28, \mathrm{~m}$ & & \\
\hline 21 & $69.8, \mathrm{CH}$ & $3.36, \mathrm{~m}$ & & $21-\mathrm{OH}, 25-\mathrm{OH}$ \\
\hline $21-\mathrm{OH}$ & & $4.20, \mathrm{~m}$ & $20,21,22$ & $\mathrm{H}-21, \mathrm{H}-25$ \\
\hline 22 & $37.3, \mathrm{CH}_{2}$ & $1.28, \mathrm{~m}$ & & \\
\hline 23 & $20.9, \mathrm{CH}_{2}$ & $1.32, \mathrm{~m}$ & & \\
\hline 24 & $37.3, \mathrm{CH}_{2}$ & $1.29, \mathrm{~m}$ & & \\
\hline 25 & $68.1, \mathrm{CH}$ & $3.54, \mathrm{~m}$ & 23,27 & 21-OH, 25-OH, H-27 \\
\hline $25-\mathrm{OH}$ & & $4.37, \mathrm{~d}(4.4)$ & $24,25,26$ & $\mathrm{H}-21, \mathrm{H}-25$ \\
\hline 26 & $44.4, \mathrm{CH}_{2}$ & $1.42, \mathrm{~m}$ & & \\
\hline 27 & $65.8, \mathrm{CH}$ & $3.79, \mathrm{dq}(13.5,6.4)$ & $25,26,29$ & H-25, 25-OH, 27-OH, H-29, 29-OH \\
\hline $27-\mathrm{OH}$ & & $4.47, \mathrm{~d}(4.9)$ & 27 & $\mathrm{H}-27$ \\
\hline 28 & $44.08, \mathrm{CH}_{2}$ & $1.39, \mathrm{~m}$ & & \\
\hline 29 & $66.6, \mathrm{CH}$ & $3.61, \mathrm{~m}$ & 28,31 & $\mathrm{H}-27,29-\mathrm{OH}$ \\
\hline
\end{tabular}

J Nat Prod. Author manuscript; available in PMC 2011 September 24. 


\begin{tabular}{|c|c|c|c|c|}
\hline Position & $\delta_{\mathrm{C}}^{a}$ & $\delta_{\mathbf{H}}(J \text { in } \mathbf{H z})^{b}$ & HМBC $^{b}$ & TOCSY $b$ \\
\hline $29-\mathrm{OH}$ & & $4.28, \mathrm{~d}(5.2)$ & 28,30 & H-29 \\
\hline 30 & $37.5, \mathrm{CH}_{2}$ & $1.31, \mathrm{~m}$ & & \\
\hline $31 \mathrm{a}$ & $21.0, \mathrm{CH}_{2}$ & $1.29, \mathrm{~m}$ & & \\
\hline $31 b$ & & $1.22, \mathrm{~m}$ & & \\
\hline 32 & $38.1, \mathrm{CH}_{2}$ & $1.29, \mathrm{~m}$ & & \\
\hline 33 & $66.5, \mathrm{CH}$ & $3.31, \mathrm{~m}$ & 32,34 & 33-OH, H-35 \\
\hline $33-\mathrm{OH}$ & & $4.29, \mathrm{~d}(6.03)$ & 33,34 & $\mathrm{H}-33, \mathrm{H}-35$ \\
\hline 34 & $37.3, \mathrm{CH}_{2}$ & $1.49, \mathrm{~m}$ & 35 & H-35 \\
\hline 35 & 73.6, $\mathrm{CH}$ & 5.00, ddd $(10.2,4.3,2.2)$ & $1,33,41$ & $\mathrm{H}-33, \mathrm{OH}-33, \mathrm{H}-34, \mathrm{H}-36, \mathrm{H}-37 \mathrm{~b}, \mathrm{H}_{3}-41$ \\
\hline 36 & $36.0, \mathrm{CH}$ & $1.66, \mathrm{~m}$ & 35 & $\mathrm{H}-35, \mathrm{H}-37 \mathrm{~b}, \mathrm{H}_{3}-41$ \\
\hline $37 \mathrm{a}$ & $31.6, \mathrm{CH}_{2}$ & $1.31, \mathrm{~m}$ & 41 & H-37a, H-38a \\
\hline $37 b$ & & $1.06, \mathrm{dd}(17.7,8.9)$ & & H-36a, H-37b \\
\hline $38 \mathrm{a}$ & $28.8, \mathrm{CH}_{2}$ & $1.31, \mathrm{~m}$ & & $\mathrm{H}-37 \mathrm{~b}$ \\
\hline $38 b$ & & $1.23, \mathrm{~m}$ & & \\
\hline 39 & $22.3, \mathrm{CH}_{2}$ & $1.26, \mathrm{~m}$ & 40 & $\mathrm{H}_{3}-40$ \\
\hline 40 & 13.6, $\mathrm{CH}_{3}$ & $0.86, \mathrm{t}(7.0)$ & 38,39 & $\mathrm{H}-35, \mathrm{H}-39$ \\
\hline 41 & $14.4, \mathrm{CH}_{3}$ & $0.80, \mathrm{~d}(6.9)$ & $35,36,37$ & $\mathrm{H}-36$ \\
\hline 42 & $24.5, \mathrm{CH}_{3}$ & $1.85, \mathrm{~s}$ & $2,3,4$ & \\
\hline
\end{tabular}

$a_{125 \mathrm{MHz}}$.

$b_{600 \mathrm{MHz}}$ 